altered its appearance in any appreciable way, I ask whence comes the continuous magnetic supply?

Again, when a lady has had for a great many years a cedar work-box which has never failed in its characteristic odour, it is a natural question to ask, whence comes the smell? The statement in books, both of physics and physiologv, is that something material is given off from the wood which alights on the olfactory membrane of the nose. This is purely gratuitous, as the statement is without a shadow of proof, the box being to all appearances in no way diminished in size or otherwise altered. If the hypothesis, for it is nothing more, fails, how does the case differ in principle from that of radium?

S. W.

\section{Normally Unequal Growth as a Possible Cause of Death.}

I HAVE found from a good many years' experience that it is frequently difficult to assign any definite cause of death to the lower Vertebrata which die in the Zoological Society's Gardens from time to time. The examination of a large example of the Japanese salamander (Megalobatrachus japonicus), which lived for a good many (nineteen) years here, and measured some three feet in length, has suggested to me a rather curious and truly " natural " cause of death -if my inferences be correct. The animal showed no obvious signs of disease in any organ. Judging from its length it must have been old, for a specimen three feet long is asserted to have been at least fifty-two years old (vide Gadow, Cambridge Natural History, "Amphibia and Reptiles," p. 99). Comparing this specimen with one some twenty inches in length I found that the size of the heart, as of the other organs, was, as might be expected, actually larger, but that all the subdivisions of the heart were of the same proportions in the two animals. But in the course of a dissection of the heart it was plain that the two series of valves, which lie respectively at the anterior and at the posterior end of the pylangium, were so small, relatively speaking, that, when forced backwards by the pressure of blood in the entire conus arteriosus, they would not meet in the middle line. On the other hand, in the smaller salamander the three valves in question were in the first place situated closer together than in the large animal, being nearly in actual contact, and in the second place their size was so great in relation to the diameter of the pylangium that they would-or, I should rather say, could -meet after the systole of the ventricle. The fact is that these valves do not appear to grow pari passu with the general increase in size of the heart and the conus arteriosus. My own observations as to the small size of the valves in the large example are quite in accord with those of Hyrtl (Cryptobranchus japonicus, Vindobonae, I865), who dissected an animal two and a half feet in length, and figures the valves, incorrectly as I believe in some particulars, but correctly in representing them to be of small relative size. It might be suggested, therefore, that the imperfection of the circulatory mechanism necessarily caused by the condition of the valves would lead to serious disturbances, and perhaps to death. If so the animal has a term put to its life by the mere fact that, while the heart grows with the increase in bodily size, the semilunar valves of the conus arteriosus do not.

FRANK E. BEDDARD.

Zoological Society's Gardens, London, N.W.

\section{Can Carrier-pigeons Cross the Atlantic?}

Could any of your readers give me an answer to this query? It is stated in the London Standard (April 2o, circ $\hat{a})$ that this feat was accomplished in 1886 , when three out of nine American carrier-pigeons set free in London returned to their home-huts. I have hitherto been unsuccessful in getting the authority for this particular experiment. From the points of view of bird migration and of seed dispersal, it is a query of considerable importance. H. B. Guppy.

21 Henleaze Gardens, Westbury, Bristol, September 2 I.

\section{A TECHNICAL SCHOOL FOR THE HIGH- LANDS OF SCOTLAND.}

THE difficult problem of catering for the educational needs of remote and isolated rural districts has been dealt with practically in this country by such enlightened benefactors as the Countess of Warwick in her school at Bigods, near Dunmow, in Essex, which has been carrying on its useful work for some five years, and which is now about to be made still more strictly into a school of agriculture, so as to bring it into harmony with the requirements of the district and of the counties which it serves. Lady Warwick's sister, the Duchess of Sutherland, has faced the still more difficult problem of providing a technical school for the Highlands of Scotland, and a preliminary account of the first scheme was given in these columns at the time of its inception (NATURE, vol. lxv. p. 106 , December 5, I901). The work thus set going by Her Grace was formally inaugurated on September 8 by Lord Balfour of Burleigh, Secretary for Scotland, at a public ceremony held for the purpose of laying the memorial stone. The building, the design of which is by Mr. Dick Peddie, of Edinburgh; is already several feet above its foundations, and is situated on the picturesque slope of a hill overlooking the little town of Golspie, on the shore of Dornoch Firth, and within two miles of the beautiful grounds of Dunrobin Castle, the Scottish home of the Sutherlands. The main features of the educational scheme, as set forth in the statement published in our first notice, have been adhered to, but the details of a curriculum suitable for requirements of such a very diverse nature as have to be met in this! remote Highland district can only be worked out by actual experience-it will be a case, as Lord Balfour said at the meeting, of solvitur ambulando. How diverse these conditions are will be realised when it is pointed out that the industries which have to be catered for are agriculture, almost entirely of the " crofting" type, textiles and dyeing, small mechanical trades and handicrafts, and fishing.

The ceremony on September 8, rendered picturesque by the surroundings and by the great gathering of some 2000 people from the neighbourhood and from all the towns and villages served by the Highland Railway from Inverness northwards, was opened by the singing of the Hundredth Psalm, and by a prayer for the success of the undertaking by Archdeacon Sinclair. The gathering was in itself a memorable one, the Duke of Sutherland, who presided, being supported by the Duchess and their family, by the Duke and Duchess of Portland, Mr. Andrew Carnegie and his partner Mr. Henry Phipps, Mr. R. B. Haldane, K.C., M.P., Prof. Meidola, by representatives of nearly all the leading Scottish families, by Members of Parliament, Provosts and Sheriffs, the Principals of the Scotch universities, the chairman of the governors of the Glasgow and West of Scotland Technical College, the conveners of the county councils, and by educationists of every class, including professors and inspectors of schools. Mr. James Macdonald, W.S. of Edinburgh, the hon. secretary of the school committee, had made himself responsible for the organisation of the meeting, which was in every way successful. After the laying of the stone, Lord Balfour said in the course of his speech :-

"This is to be a school for Sutherland and these other counties (Caithness, Ross and Cromarty). It is not only to be accessible to Sutherland and these other counties, as any other school might be, but it is a school expressly designed for the needs and wants of the district in which we are met. Its curriculum will be based on a careful study of the condition of things as they now exist, and will have, as the promoters

No. 1769 , VOL 68] 
clearly indicate, a direct reference to the special wants and wishes of those in the district around it. I think I am not wrong in claiming for this departure on the part of its promoters that it is to be a new fact in the educational history of our country ... this school is not merely a copy-still less is it intended to be a rival of other educational agencies and institutions, whether they be of an elementary or of a higher or secondary type ... it is an intelligent effort and a new attempt to solve a difficult problem, and one which never was more difficult than it is to-day, as to whether you can, in regard to any given population, living under certain given conditions, which perhaps cannot in the district b: much altered, give education and ameliorate for them those conditions, and if so, what kind of education will best do it... in this matter the promoters have set themselves not to consider codes or grants or examination successes.'

In view of the fact that the Sutherland Technical School is entirely due to private enterprise, and is therefore in the same position as regards support from public sources as Lady Warwick's school in Essex, it will be of importance to those interested in this phase of recent educational development to give another extract from Lord Balfour's speech :-

- This school is an experiment, a highly desirable and promising experiment, but not one on which any local authority could itself venture. Nor could the Education Department do it, much as we approve of the proposal. It is work for private initiative, for private enterprise, and for individual enthusiasm. May I just say in passing that if we remodel our educational system, as I for one sincerely hope we shall do, that we bring it up to date, and that we make it more complete than it is at present, let us leave some place for free individual action. Boards, committees and departments are all very well in their way, but they are apt to be regulative rather than initiative, critical rather than constructive. Many advances in education must start outside the established system. Do not let us keep private institutions out of that system. Widen your local powers if you like. Let them take advantage of and help those institutions outside their own system which are well managed. In the present instance, as I understand, the local authority - the technical committee of the county-has promised a considerable measure of support, and under the freer conditions of State recognition that have obtained in recent years, we do not anticipate there will be any difficulty in our helping them. What the exact measure of that support may be, and on what conditions it is given, it is difficult to say until the plan of the school work becomes more defined; but I can give you this assurance with every intention of seeing it carried out, that the progress of the school will be watched with interest and sympathy by the officials of my department, and that as large a measure of support will be accorded it as the conditions laid down by Parliament for supporting education will allow."

In moving a vote of thanks to Lord Balfour, the Duchess of Sutherland, in the course of an admirable speech, made some remarks so thoroughly in harmony with the views of the advocates of the newer education that they may appropriately be transferred to these columns:-

"It has been suggested that in Scotland the old system of what is called classical education is sufficient to meet all requirements; that the secondary departments of the primary schools are fairly equipped, and that if a boy wishes to pursue so-called technical studies he might be awarded a sum of money to enable him to go into large cities and there pursue them. It has even been suggested that essentially a rural agricultural school must in its aims be opposed to mental culture. Such ideas are fallacies. I am afraid that the studies of the immortal wonders of the classics and of what are so strangely called the deal languages have too of ten proved a dead study to the student. A mere mechanical acquisition of knowledge leads us nowhere. How would Aristophanes, author of the "Birds" and the "Clouds," how would Hesiod, the poet of the husbandman, how would Theocritus and Virgil, singers of pastoral delights, turn in their graves if they could know that only their dog-eared books spoke their music to our children, and that the chords from which that music sprang were unassayed, unloved, even unnoticed by the scholars of to-day. Not, indced, that the children will not notice, and that they cannot love, but the present time education has, until verv recently, driven them away from the region of growth to the region of the cut and dried. They live in this inspiring country at an age when the swelling of the grain on the hillside, the habits of the birds, the marvellous nature of a handful of earth, might rouse a passionate interest and quicken every faculty of observation. In a school such as this we would draw culture from its source until the youth, who for himself has seen and understood, should turn away from the intoxication of his own experiments to the books of those who long ago saw and understood, and there find a background for his own ideas and an echo to his conclusions. I deny . . . that there is any divorce between these imaginations and the practical conditions of to-day. . . . This is a scientific age; that is why we need the scientific schools. Every hour fresh marvels of the mysterious nature which surrounds us are being by science revealed."

The Duke of Portland, in seconding the vote of thanks, dwelt forcibly upon the point that the new school would not in any way compete with or overlap the work of existing institutions. A vote of thanks to the donors of the building fund, the Duke of Sutherland and Mr. Andrew Carnegie, was proposed by Mr. R. B. Haldane, M.P., and seconded by Sheriff Guthrie, who in the course of his speech pointed out the immense amount of harm that had been done to the cause of education in this country by certain classes of writers and speakers whose sole function had been to act the part of destructive critics without making any constructive contributions of any kind. $\mathrm{Mr}$. Carnegie replied on behalf of the donors.

The school thus launched is intended to accommodate forty residential pupils and a limited number of day pupils from the immediate neighbourhood. The building will contain fifty-six rooms, of which fourteen are to be used as class-rooms, laboratories, and workshops. The cost of erection and equipment is estimated at $16,000 l$, of which $8000 l$. have been contributed by the Duke of Sutherland and $8000 l$. by Mr. Carnegie. The Duke of Portland and many others interested in the district have also given substantial aid. Forty bursaries of $30 l$. each have been given by the Duchess of Sutherland, Mrs. Carnegie, and many other generous friends of the movement. The site of the school has been given by the Duke of Sutherland. The educational experiment which the enlightened zeal of the Duchess of Sutherland has now set going in the extreme north merits the warmest sympathy of our readers and of all who have the cause of scientific education at heart. The undertaking is unquestionably a bold one, and if, as Lord Balfour intimates, it is to be left solely to private enterprise in this country to initiate this kind of work, it is a matter of congratulation that we have among us such enthusiasts as the noble sisters whose names will always be associated with the cause of scientific education in rural districts. The school at Golspie will be unique of its kind in the north of Scotland. The Highlander by temperament and the surroundings of his birth, by

No. I 769 , voL. 68] 
the excellence of his primary education and by the natural zeal which he possesses for the acquisition of knowledge is certain to rise to the opportunity now to be placed in his way. It is unnecessary to institute comparisons, but it may be safely said that this Highland school will have raw material to deal with of which many an English rural district might well be envious.

\section{RESIN-TAPPING.}

CRUDE resin is almost always obtained from pines of various species, e.g. Pinus Pinaster or $P$. maritima in Europe, $P$. palustris, $P$. Taeda and $P$. australis in America, and $P$. longifolia, P. excelsa, $\alpha \mathrm{c}$. in India. It may also be obtained from other Conifers

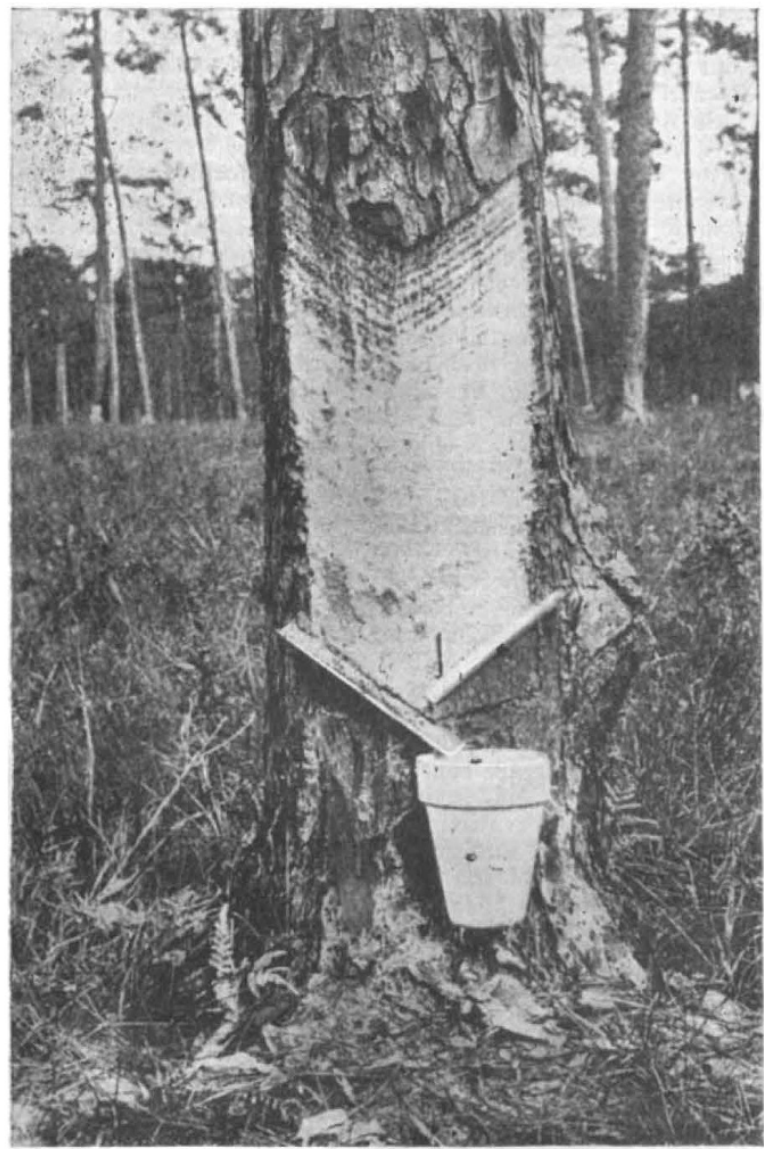

FIG. x.-Cup and Gutters used in collecting Crude Turpentine.

(spruce, larch, \&c.), and even from some Dicotyledons. The universal practice is to cut through the cortex and to allow the crude viscous liquid oleo-resin to drip into some form of receptacle, e.g. a hole in the sandy soil, or an excavated "box" in the foot of the bole, or a metal or earthenware "pot" hung on to the tree.

From the crude resin thus obtained, numerous other products are derived by means of distillation, \&c. Among these spirits or oil of turpentine, colophany (rosin), pitch and tar are the most important, and the quantities of these substances required annually for naval purposes, for making varnishes, sealing-wax \&c., are so great that the resin industry is a large and lucrative one.

There are certain limits to the working of a pine- tree as a resin-factory which increase the expense of production so considerably that it has long been the practice in America recklessly to abandon a tract worked for resin and push forward into newer regions. These limits of production depend especially on the fact that cutting large holes in the basal parts of the bole of a tree is bound to result in disaster sooner or later; and since the American plan systematically pursued has been that of boxing "-i.e. cutting large holes in the wood below, into which the resin from the cut and scarified cortex should slowly drain-the inevitable result has been the wholesale destruction of the trees by means of rot-fungi, wind throwing, ground fires, \&c.

This state of affairs has naturally driven the authorities to seek for some better methods of extracting the resin, and in a recent publication ${ }^{2}$ Dr. Hertz brings forward the results of a very complete set of experiments designed to compare the yield and value of the resin obtained by the old "boxing " method, and that obtained by a modification of the European systems.

The latter consists in allowing the resin from the periodically scarified cortex and young wood to drain down into two slanting spouts of thin tin, which direct it in to a pot hung properly beneath. The advantages claimed for the improved system are, a longer life of the tapped tree, a greater yield of resin all the time, less waste in catching the resin, diminished evaporation of volatile products, and less dirt and discoloration as the liquid flows over the face exposed, as well as other and minor points.

These matters, expressed in terms of money value, are given in a series of tables, from which the following is the extract only :-

\begin{tabular}{|c|c|c|c|c|}
\hline Half crop. & $\begin{array}{l}\text { From } \\
\text { dip. }\end{array}$ & $\begin{array}{l}\text { From } \\
\text { scrape. }\end{array}$ & Total. & Excess. \\
\hline $\begin{array}{l}\text { Second year. } \\
\text { Cups } \ldots \ldots . . \\
\text { Boxes }\end{array}$ & $\begin{array}{l}\text { Dollars. } \\
266.34 \\
\text { 104.5I }\end{array}$ & $\begin{array}{l}\text { Dollars. } \\
49.25 \\
66.95\end{array}$ & $\begin{array}{l}\text { Dollars. } \\
315.59 \\
\text { I } 71.46\end{array}$ & $\begin{array}{l}\text { Dollars. } \\
\text { 144. } 13\end{array}$ \\
\hline Third year. & & & & \\
\hline $\begin{array}{c}\text { Cups } \ldots \ldots \ldots \ldots \ldots \ldots \ldots \\
\text { Boxes } \ldots \ldots \ldots \ldots \ldots \ldots \ldots \ldots\end{array}$ & $\begin{array}{r}171.27 \\
39.49\end{array}$ & $\begin{array}{l}27.44 \\
26.57\end{array}$ & $\begin{array}{r}198.7 \mathrm{r} \\
66.06\end{array}$ & 132.65 \\
\hline Fourth year. & & & & \\
\hline Cups..$\ldots \ldots \ldots \ldots \ldots \ldots \ldots \ldots \ldots \ldots$ & 167.33 & 29.23 & 196.56 & 132.56 \\
\hline Boxes $\ldots \ldots \ldots \ldots \ldots \ldots$ & 36.09 & 27.91 & 60.00 & \\
\hline
\end{tabular}

The bulletin is admirably written, and affords an excellent example of what may be done by a properly trained expert in learning the methods of an old industry practised in another country, improving and adapting them to the wants of his own locality, and, above all, in demonstrating his points so convincingly by means of experiments that the most prejudiced of his workmen becomes reconciled to the innovations.

The illustrations, of which we select one, are well chosen, sufficient, and admirably executed.

\section{THE SOUTHPORT MEETING OF THE BRITISH ASSOCIATION.}

THE Southport meeting of the British Association was concluded as we went to press last week. At the meeting of the General Committec on Wednesday, September 16 , the resolutions sent forward by the Committee of Recommendations, and printed in last week's NATURE, were adopted. In addition, the two following resolutions were carried:-

(I) That the systematic investigation of the upper currents of the atmosphere by means of kites or

1 "A New Method of Turpentine Orcharding," by Dr. C. H. Hertz. U.S. Department of Agriculture, Bull. xl., 1903.

No. I 769, voL. 681 